\title{
TRÁFICO ATLÂNTICO, ESCRAVIDÃO E RESISTÊNCIA NO BRASIL
}

\author{
Maria Jorge dos Santos Leite ${ }^{1}$
}

\section{Resumo}

Entre os séculos XVI e XIX, milhares de homens e mulheres negros perderam sua condição humana ao serem capturados e transformados em mercadoria negociável, através de uma atividade comercial denominada tráfico atlântico, que envolveu sujeitos de três continentes: Europa, África e América, culminando na escravidão negra, da qual o Brasil participou intensamente. Este trabalho tem como objetivo revisitar a história da escravidão no Brasil, através da análise das formas de resistência apresentadas pelos escravizados, desde sua retirada da África, até a formação de quilombos. Reflete, ainda, as contradições entre os ideais liberais que deram sustentação às lutas por liberdade política e econômica no Brasil e a manutenção da escravidão após a Independência de 1822; bem como, as lutas encabeçadas pelos ex-escravos a partir Abolição, em 1888, na defesa do direito à cidadania e contra o racismo. A metodologia de pesquisa foi pesquisa bibliográfica - revisão de literatura- através da análise da contribuição de vários autores para a história da escravidão e resistência no Brasil, do movimento negro pós-abolição e da questão racial.

Palavras-chave: Tráfico, escravidão, resistência, movimentos, racismo, preconceitos.

\section{Introdução: O Brasil e a escravidão}

O tráfico foi responsável pelo arrebatamento de milhões de homens e mulheres de suas nações na África para serem escravizados na América, especialmente em terras brasileiras. Essa atividade comercial, via oceano Atlântico, foi um grande investimento econômico e cultural do capitalismo europeu, que marcou a formação do mundo moderno e a criação de um novo sistema econômico mundial. A política expansionista dos países europeus, sobretudo das monarquias ibéricas (Portugal e Espanha), tinha como propósito a obtenção de lucros rápidos através do comércio de especiarias com a Ásia, a extração de ouro na África subsaariana, e da exploração de terras na América - de preferência não habitadas- onde pudessem ser cultivados produtos agrícolas de grande procura na Europa. Para garantir uma produção agrícola em grande escala e extraordinários lucros, foi instituído o tráfico e a escravização desregrada de homens e mulheres no empreendimento colonial português dentro do Brasil.

1 Doutora em Educação Brasileira pela Universidade Federal do Ceará/UFC. Professora-adjunta da Universidade de Pernambuco/UPE 
O Brasil envolveu-se plenamente nessa trágica aventura da escravidão. Presume-se que tenham sido trazidos forçadamente para o nosso país cerca de $40 \%$ dos africanos vitimados pela escravidão moderna. Foram eles e seus descendentes que constituíram a quase total força de trabalho existente durante os mais de trezentos anos em que vigorou a instituição escravocrata brasileira. Assim, a escravidão acabou por penetrar todos os aspectos da sociedade brasileira durante esse período. Os afro-brasileiros deram vida e fizeram movimentar "engenhos, fazendas, minas plantações, fábricas, cozinhas e salões” (REIS e GOMES, 1996,p.19) e deixaram suas marcas em outros elementos da vida material e cultural do Brasil, "agricultura, culinária, religião, língua, música, artes, arquitetura.

Tão intensa quanto a própria escravidão foram os tipos de resistência apresentados pelos sujeitos escravizados ao sistema que lhes fora imposto. A resistência revelou-se desde a recusa vã em deixar suas terras, famílias, culturas e histórias na África, passando pela rebelião durante a insalubre travessia do Atlântico, até às formas mais radicais, como assassinato de seus escravizadores, nos locais de trabalho forçado. No entanto, são os movimentos organizados durante o processo de escravização- fugas e formação de quilombos - que revelam a dimensão da resistência à escravidão. Assim como os movimentos ocorridos depois da Abolição, são os que melhor explicam a luta dos ex-escravos por liberdade, respeito, dignidade e direitos no Brasil.

Movimentos expressivos envolvendo grupos negros percorrraem toda a história da escravidão no Brasil. Até a abolição da escravatura, em 1888, esses movimentos eram quase sempre clandestinos e de caráter radical, considerando que a libertação dos negros escravizados era seu principal objetivo. Como os escravos eram considerados propriedade privada, fugas e insurreições, além de causarem prejuízos econômicos, ameaçavam a ordem vigente e tornavam-se motivos de violenta repressão, não somente por parte dos proprietários de escravos mas do próprio Estado. Mas, a resistência sobreviveu apesar da repressão, e não desapareceu com a abolição. Pois, com a extinção da instituição escravocrata, impõe-se aos ex-escravos a necessidade de lutar contra o preconceito racial e pelo reconhecimento de direitos relacionados à cidadania, durante séculos negados.

Em se tratando de um fenômeno do mundo moderno, a escravidão foi contraditória em diversos sentidos. Além de ferir princípios fundamentais como a vida, a dignidade, a igualdade e a liberdade; a escravidão também contrariou os próprios fundamentos teóricos que deram sustentação ao capitalismo, como os princípios do Liberalismo, que primavam pela liberdade 
econômica, política e, logicamente, a liberdade individual.

No Brasil, os movimentos pela Independência, e a própria Constituição de 1824, foram baseados nos princípios liberais. No entanto, a escravidão não foi abolida juntamente com a abolição do sistema colonial; ela se estende por mais 66 anos, durante os quais Escravidão e Liberalismo andavam lado a lado, constituindo uma verdadeira "comédia ideológica", no entender de Roberto Schwartz(1992).

A abolição foi historicamente conquistada pelos próprios escravizados, a partir de cada forma de resistência por eles apresentadas. Nos últimos anos de existência da instituição escrava a resistência negra ganhou reforço do abolicionismo, movimento composto por sujeitos livres e contrários à manutenção do sistema escravocrata. Não obstante, a libertação não significou a instituição automática dos direitos de cidadania dos ex-escravos. Estes, precisaram organizar movimentos de luta pela defesa de seus direitos, bem como contra os estereótipos, racismo e preconceitos que os vitimaram na sociedade de classe brasileira.

\section{O tráfico atlântico e resistência}

A fase expansionista do capitalismo comercial europeu levou portugueses, espanhóis, e outros povos, a empreenderem um ambicioso projeto de exploração de novas terras e povos fora da Europa. Depois de alcançarem o litoral atlântico da África, ainda no século XV, os portugueses conheceram o comércio de seres humanos praticado internamente nesse continente. Não é objetivo deste trabalho discutir os significados dessa atividade existente no interior do continente africano; interessa-nos, pois, compreender que, visando lucros cada vez mais altos e rápidos, os portugueses resolveram "entrar no negócio" da comercialização e escravização de humanos. Começaram ali mesmo na África uma prática de escambo, entre europeus e africanos, na qual os primeiros ofereciam aos segundos produtos do interesse destes: tecidos, vinhos, cavalos, ferro, e outros. Recebiam em troca mercadoria humana - homens, mulheres e crianças-, que em suas mãos tornavam-se objeto de dupla exploração: mercadorização, através tráfico para a América e a expropriação de sua força de trabalho, dentro do sistema de escravização nas colônias portuguesas, especialmente no Brasil. Dessa forma, o tráfico de africanos transformou-se numa das atividades mais lucrativas para o Estado português e das elites agrária e escravocrata no Brasil. 
A escravidão, uma nefasta prática de desumanização, coisificação e comercialização de pessoas, fora uma atividade bastante lucrativa, porém difícil de administrar. Os entraves a esta eram impostos pelas próprias vítimas da escravização, os negros africanos, que responderam desde sempre ao processo de coisificação, com as mais variadas formas de resistência. As primeiras manifestações de resistência à escravidão foram enfrentadas pelos escravizadores ainda na África, no momento em que os negros e negras eram capturados, amarrados e amontoados em armazéns, à espera dos navios que os trariam para o Novo Mundo. Como uma viagem entre a África e o Brasil era muito dispendiosa, esses humanos, vitimados pela mercadorização, permaneciam por vários dias trancados à espera da formação de uma carregamento completo, para então serem transportados até o destino de sua escravização. Durante a espera não permaneciam quietos, resistiam de todos os modos possíveis, sendo mais comum a rebelião. Há registros de rebeliões na ilha de são Tomé; e também a bordo dos navios negreiros irromperam revoltas nas quais, os escravos matavam marinheiros e europeus, jogava-os nas águas salgadas do Atlântico e tomavam o comando dos navios. Alguns navios foram aportar em ilhas povoadas apenas por índios, ou na costa da América Central. E quando resistir se tornava impossível, restava-lhes aguentar as condições desumanas da viagem que, muitas vezes causavam-lhes à morte.

Os muitos que sobreviveram à longa e penosa travessia do Atlântico, passavam a desempenhar importante papel como mão de obra escrava distribuída por inúmeras atividades no litoral e interior da colônia, onde produziam as condições materiais para o acúmulo de excedente ambicionado por seus escravizadores.

No entanto os africanos não contribuíram apenas no âmbito do trabalho, mas marcaram a sociedade brasileira em outros aspectos: na forma como se organizavam em "nações", na constituição de famílias (muitas vezes simbólicas), nas manifestações de religiosidade (catolicismo, islamismo e candomblé e da cultura (língua, lundu, batuque e capoeira). (MATTOS, 2007, p.13).

Nesse sentido, as formas de organização, as expressões culturais, a religiosidade e o modo de vida africanos, que sobreviviam apesar da escravidão, expressavam-se, também como formas de resistência ao processo de coisificação ao qual estavam submetidos. 


\section{Escravidão no Brasil: fugas e quilombos}

Onde houve escravidão houve resistência e de diversas maneiras. Mesmo sob constantes ameaças, os escravos negociavam espaços de autonomia com os senhores, faziam "corpo mole" no trabalho, quebravam ferramentas, incendiavam plantações, agrediam senhores e feitores, rebelavam-se individual ou coletivamente(REIS E GOMES, 1996). Entretanto foram as fugas, seguidas de formação de quilombos, os maiores símbolos da resistência escrava no Brasil.

A palavra quilombo tem a conotação de uma associação de homens, aberta a todos sem distinção de filiação a qualquer linhagem, na qual os membros eram submetidos a dramáticos rituais de iniciação que os retiravam do âmbito protetor de suas linhagens e os integravam como co-guerreiros num regimento de super-homens invulneráveis às armas de inimigo. (MUNANGA, 1996,p. 60).

Da mesma forma que promoviam as fugas e revoltas, os escravos também aproveitavam a existência de pequenos espaços para a negociação. Espaços esses que eles próprios conquistaram ao mostrarem aos senhores a necessidade de certa autonomia para o bom funcionamento do sistema escravista como o cultivo de roças próprias um dia de descanso por semana. Mas essas eram situações de exceção, via de regra os conflitos entre escravos e senhores, quando não explícitos, estavam sempre latentes.

A fuga era um dos meios de resistência à escravidão mais corriqueiro. Os escravos costumavam fugir em grupo, o que resultava na formação de quilombos. Porém, algumas vezes, as fugas eram realizadas individualmente, ocasião em que os fugitivos procuravam abrigo na residência de algum liberto ou livre conhecido, viajavam para outra região ou se estabeleciam em áreas periféricas da cidade. Para não serem presos, os escravos fugidos fingiam ser negros libertos, desempenhando algum tipo de atividade para sua sobrevivência e fazendo parte do cotidiano periférico urbano.

Dentre as fugas existiam aquelas que visavam reivindicar melhores condições de trabalho e de sobrevivência, a manutenção de direitos adquiridos, como os dias de descanso, permissão para o cultivo de roças próprias, organização de festas e vivência de práticas culturais. Mas, também, , havia fugas que rompiam de vez com a relação escravo e senhor. Isto poderia acontecer, por exemplo, quando o proprietário recusava-se em aceitar a quantia em dinheiro reunida pelo escravo 
em troca de sua carta de alforria; ou quando o escravo entendia que estava sendo castigado em excesso.

As fugas de escravos eram, com frequência, mencionadas em anúncios de jornais, feitos pelos proprietários que procuravam seus cativos fugidos, ou por qualquer outra pessoa que encontrasse escravos vagando pela cidade sem possuir permissão para isso. Esses escravos fugidos, quando encontrados, eram levados à prisão e um anúncio com as suas características era publicado, solicitando que seus proprietários fossem resgatá-los. Sendo resgatado pelo proprietário o escravo raramente escapava dos castigos físicos, que compreendiam desde a prisão no tronco, o açoitamento até o uso da gargalheira ${ }^{2}$. Mesmo correndo riscos de perder sua "propriedade", muitos senhores cometiam excessos ao castigar violentamente seus escravos chegando a provocar a morte destes.

Por outro lado, diante da difícil condição do cativeiro - dos castigos e das punições de seus senhores -, agravadas pela distância de sua terra de origem e de seus familiares, muitos escravos viam no suicídio a única ou a última forma de livrar-se da escravidão. Alguns escravos fugidos constituíam comunidades independentes, mas não muito isoladas, para que pudessem interagir com a sociedade, comercializando sua produção agrícola, mesmo que de forma clandestina, com a ajuda de pequenos comerciantes, agricultores e até mesmo escravos.

Uma das características das comunidades formadas por escravos fugidos era a existência de alianças com outras comunidades: indígenas, comerciantes, libertos e pequenos agricultores. Conhecidas como quilombos ou mocambos, essas comunidades foram aparecendo em várias localidades brasileiras: próximas aos engenhos, às minas de ouro e pedras preciosas, nos sertões e nos campos. À medida que os quilombos iam surgindo, cada vez em maior número e em diferentes locais, a repressão aumentava, sendo feita por iniciativa dos proprietários, que colocavam os “capitães-do-mato" em busca dos fugitivos ou contratavam agregados para capturá-los, ou por iniciativa governamental, com expedições militares e leis mais severas.

O fenômeno do aquilombamento, e outras formas de resistência, tem sido bastante estudado no continente americano. A quantidade e qualidade desses estudos variam de um país para outro, são bem estudados, por exemplo, os quilombos da Jamaica e do Surinane. "No Brasil essa memória não é absolutamente apagada se consideradas as comunidades remanescentes de quilombos que

2 Espécie de coleira de ferro com hastes e ganchos acima da cabeça. 
realmente podem traçar seu passado até agrupamentos constituídos antes da abolição, em 1888" (REIS e GOMES, 1996, p.10). Ainda assim há pesquisadores que apontam para uma lacuna na produção historiográfica sobre grupos negro no pós-abolição (FUNES, 1995).

Os estudos sobre os negros durante a escravidão e depois da abolição apontam para a existência de quilombos em quase todos os estados brasileiros. Há registros históricos sobre quilombos no Maranhão e Grão-Pará, Rio de Janeiro, São Paulo, Minas Gerais, Bahia e Pernambuco. Os quilombos pernambucanos são os que mais têm despertado o interesse dos pesquisadores devido à intensidade da atividade escrava nos engenhos de cana de açúcar e do antigo movimento quilombola que se desenvolveu na capitania/província de Pernambuco.

O tráfico de escravo destinado a abastecer Pernambuco teve seu auge entre o final do século XVIII e início do século XIX, quando o algodão tornou-se o grande produto para exportação. Nessa época, surgiram vários quilombos na região, entre eles o mocambo do Catucá ou Maluguinho, criado por volta de 1817, próximo a Recife. Esse quilombo conseguiu resistir por muito tempo, sendo destruído somente no final da década de 1830, por uma expedição militar organizada pelo governo imperial. Os Maluguinho sobreviviam da agricultura de subsistência, caça e de roubos aos engenhos de açúcar. Contavam ainda, como estratégia de sobre vivência e proteção, com ajuda de escravos libertos e até de livres pobres de fora da comunidade quilombola.

Entretanto, o quilombo mais conhecido, não só em Pernambuco e região, mas em todo Brasil, foi o de Palmares, localizado na Zona da Mata, a aproximadamente 70 quilômetros do litoral de Alagoas. Datando do século XVII, esse quilombo era composto, majoritariamente, por africanos da região centro-ocidental. Os pesquisadores de Palmares se surpreendem com a complexidade de sua estrutura e organização. Há evidências de que era composto por várias aldeias sendo que a maior delas, uma aldeia central denominada de "Macaco", estava localizada na serra da "Barriga" e contava uma população de aproximadamente seis mil pessoas, não somente escravos fugitivos, mas também índios e pobres livres que fugiram da exploração no meio aristocrático rural. Possivelmente a aldeia central possuía alguma "estrutura de urbanização": ruas paralelas, casas, capela, oficinas de fundição e produção artesanal em cerâmica, madeira e cipó extraído da floresta. Ao que parece o artesanato era apenas uma atividade complementar à agricultura, esta era a base de sustentação econômica dos quilombolas, na qual produziam milho, feijão, mandioca e cana-de-açúcar. 
As aldeias, tanto a central como as periféricas, possuíam seus chefes, o que aponta para uma descentralização de poder naquele quilombo. Contudo, apenas dois líderes, Ganga Zumba e Zumbi, configuram com maior ênfase a história política de Palmares. Para o Movimento Negro contemporâneo, principalmente o quilombola e alguns pesquisadores, eles são símbolos de resistência, força e heroísmo contra a escravidão; para outros, apenas "traidores" de seu próprio povo por "negociar" com as elites escravocratas (Ganga Zumba, conforme documento transcrito abaixo) e escravizar os irmãos negros (Zumbi).

Aos 18/06/ 1678 diante do governador Aires de Souza e Castro os palmarinos, liderados por Ganga Zumba, contrariando as diretrizes do Sistema Colonial Vigente, teriam direito à uma área delimitada onde viveriam em liberdade, podendo plantar, comercializar e tratar com os brancos, sem o fisco real, tendo que se desfazer do equipamento militar (ANDRADE, 2004, p. 71).

A fuga e a formação de quilombos era uma "rebeldia" pouco tolerada pela administração da colônia (ou do Império) e pelos proprietários de escravos. Por isso, desde 1612, expedições foram organizadas com a finalidade de destruir Palmares. Aquele aldeamento tornara-se perigoso demais, para lá convergiam os escravos- propriedade privada dos senhores- além de inspirar fugas e formação de quilombos em outras regiões.

Depois de várias investidas, o quilombo foi aniquilado, em 1694, por uma expedição comandada pelo paulista Domingos Jorge Velho, causando a morte de muitos quilombolas e a venda de outros para diversas capitanias. Zumbi, último líder palmarino, e alguns outros negros, conseguiram fugir, mas o "rei" dos quilombolas acabou sendo preso e executado em 20 de novembro de 1695. Sua cabeça foi decapitada e colocada em exposição num deprimente espetáculo público de demonstração de força e poder, através da qual os escravocratas e as autoridades coloniais deixaram bem claro que o movimento quilombola não seria tolerado.

\section{Liberalismo e escravidão}

Desde o século XVIII os ideais de liberdade se fizeram presentes em movimentos populares e burgueses organizados em diversos países. Como desdobramento histórico da conceituação de liberdade surge o liberalismo, definido como um conjunto de princípios e teorias que apresentam como ponto principal a defesa da liberdade política e econômica. No Brasil, o 
pensamento liberal se desenvolveu no século XIX tomando como base o modelo europeu, este servindo de referência constante aos liberais brasileiros, os quais examinam e modificam esse modelo a partir de sua experiência e de seu projeto(FERRAZ, 1996).

Durante muito tempo o Liberalismo se fez presente no Brasil, sem que os seus ideais fosse aplicados aos movimentos de libertação dos escravos. Segundo Carvalho (2001), as revoltas políticas que ocorreram no Brasil colônia eram elitistas, pois seus líderes eram pessoas pertencentes aos setores dominantes: militares, fazendeiros, padres, poetas. A mais popular delas foi a Revolta dos Alfaiates, em 1798. No entanto, é na revolta de 1817, de ideias claramente liberais - embora as outras também fossem- que aparecem alguns traços de uma nascente consciência de direitos socais e políticos. "Mas as ideias de igualdade não iam muito longe. A escravidão não foi tocada"(CARVALHO, 2001,p.25). Pior do que isso, com a Independência de 1822 o dilema da escravidão continuou intocável. Não poderia ser diferente: a Independência veio pelas mãos do príncipe regente português que a proclamou em seu nome - a Constituição de 1842 revela isto - e em nome de uma elite agrária dependente do trabalho escravo.

A Constituição de 1824, com todo seu liberalismo, não aboliu nem modificou a instituição escrava. Ao contrário tornou-a mais evidente. Segundo Emília Viotti da Costa, a Declaração dos Direitos do Homem, por exemplo, transcrita em parte na Constituição Brasileira de 1824, não só não escondia nada, como tornava mais abjeto o instituto da escravidão" (COSTA, 2007). Assim, a Independência, apesar de se constituir num avanço em relação aos direitos políticos, trouxe limitações em relação aos direitos civis por manter a escravidão.

O Estado brasileiro, cujo rompimento com o sistema colonial português baseara-se nos ideais liberais europeus, trazia consigo uma grande contradição: a incompatibilidade dessas ideais com a manutenção da escravidão contrariando, assim, os princípios de liberdade. Em consequência tem-se aí a desorganização da vida ideológica do Segundo Reinado, o que Roberto Schwarz denomina de comédia ideológica. Para o autor, por sua mera presença, a escravidão indicava a impropriedade dos ideais liberais( SCHWARZ, 1992).

A manutenção da escravidão e a limitação do gozo dos direitos civis e políticos aos negros libertos são evidências claras de que as ideias liberais no Brasil da segunda metade do século XIX estavam "fora do lugar", como afirma Schwarz. Aquele era um liberalismo de conveniência, acionado pela elite dominante para promover a liberdade política e econômica do Brasil em relação 
à Portugal em razão de seus próprios interesses. Assim, a igualdade de direitos contida na Carta Constitucional não passava de mera formalidade. Pois,

Apesar da igualdade de direitos civis entre os cidadãos brasileiros reconhecida pela Constituição, os brasileiros não-brancos continuavam até mesmo a ter o seu direito de ir e vir dramaticamente dependente do reconhecimento costumeiro de sua condição de liberdade(MATTOS, 2004:21).

Manutenção da escravidão e negação de direitos a negros libertos fez com que a resistência escrava se intensificasse no decorrer de todo Período Imperial. A liberdade mais do nunca tornou-se urgente e necessária. De acordo com Pinsk(2001), o fato é que o negro não tinha "jeito" ou “espírito" de escravo. Aliás, ninguém tem. O próprio ser humano é a liberdade, e não a escravidão.

Até segunda metade do século XIX, os negros escravizados lutaram praticamente sozinhos contra a escravidão. A intensificação da luta contra a escravidão é proporcionada, em termos, por forças externas. Aquelas que constituíram o movimento abolicionista. Faziam parte desse movimento profissionais como advogados, jornalistas, professores e outros, que juntos criticavam a manutenção da escravidão, dando apoio aos escravos na organização da resistência. Essa conjuntura levou à insustentabilidade da instituição escrava.

Embora muitos proprietários de escravos ainda insistissem na manutenção daquele sistema corroído, o Estado Imperial se antecipou ao "golpe final" contra a escravidão - que já era considerado como certo, e poderia vir acompanhado de manifestações de violência contra os representantes do sistema- e institui a abolição da escravidão, em 1888.

Longe de ter sido uma ação benevolente da Princesa Isabel, protagonista do ato - a assinatura da Lei que instituiu a abolição - o Estado Imperial visava preservar sua própria existência diante dos conflitos que marcaram as últimas décadas do século XIX: surgimento do Movimento Republicano, instituído a partir de 1870; conflito entre o poder imperial e a Igreja Católica e o descontentamento dos militares que levou à implantação da República, através do golpe liderado pelo Marechal Deodoro da Fonseca, em 1889.

A escravidão foi extinta, em 1888, mas a situação dos negros, ex-escravos, em quase nada foi alterada. Para Florestan Fernandes( Apud COHN, 2002), a população negra, após uma abolição na 
qual os senhores viram-se livres de seus escravos mais que estes ganharam a liberdade, busca novas condições de sobrevivência numa sociedade de classe em formação.

Não há dúvidas de que o antigo movimento quilombola consistia na negação à condição de escravos dos negros. Assim, a abolição seria, a priori, uma vitória desse movimento. No entanto,

Os ex-escravos foram abandonados à própria sorte. Caberia a eles, daí por diante, converter sua emancipação em liberdade efetiva. A igualdade jurídica não era suficiente para eliminar as enormes distâncias sociais e os preconceitos que mais de trezentos anos de cativeiro havia criado. A Lei Áurea aboliu a escravidão mas não seu legado. Trezentos anos de opressão não se eliminam com uma penada. A abolição foi apenas o primeiro passo na direção da emancipação do negro. Nem por isso deixou de ser uma conquista, se bem que de efeito limitado (COSTA, 2008, p.12).

Faltaram medidas políticas efetivas visando a integração dos ex-escravos na sociedade. Talvez porque muitos abolicionistas, a exemplo de Joaquim Nabuco, eram membros de famílias ligadas ao setor agrário e, por isso, estavam mais interessados em livrar a sociedade brasileira do "estigma" da escravidão do que cuidar do futuro dos libertos. Tais abolicionistas deram a questão do negro por encerrada após o 13 de maio; parece que "a maioria tinha estado mais preocupada em libertar os brancos do fardo da escravidão do que estender aos negros o direito de cidadania" (COSTA, 2008, p. 137) .

A instauração da República, em 1889, não trouxe nada de positivo para os libertos. Ao contrário; excluiu os analfabetos do direito de voto, eliminando a maioria do ex-escravos do eleitorado. Assim, nos anos que se seguiram à abolição, os sonhos de liberdade transformaram-se muitas vezes em pesadelo. Tendo que enfrentar muitas condições adversas, os libertos não tardaram a entender que sua luta não chegara ao fim. Caberia a eles mesmos se organizarem para defender seus direitos.

\section{Negação da cidadania, racismo e movimento negro}

Considerando os limites impostos pela abolição às condições de cidadania dos ex-escravos, os movimentos de resistência negra no Brasil não só continuaram existindo, como também começaram a trilhar novos caminhos. A partir de meados dos anos 1910, numa tentativa de lutar pelo reconhecimento de sua recém-adquirida cidadania e evoluir para organizações de âmbito 
nacional, o movimento negro elaborou suas primeiras formas de moblização no contexto pósabolicionista.

O Movimento Negro é aqui entendido como:

Todas as entidades, de qualquer natureza, e todas as ações, de qualquer tempo, aí compreendidas mesmo aquelas que visavam à autodefesa física e cultural do negro, fundadas e promovidas por pretos e negros. Entidades religiosas como terreiros de candomblé, por exemplo; assistenciais como as confrarias coloniais; recreativas como "clubes de negros"; artísticas como os inúmeros grupos de dança capoeira, teatro, poesia; culturais como os diversos "centros de pesquisa" e políticas como o Movimento Negro Unificado; e ações de mobilização política, de protesto antidiscriminatório, de aquilombamento, de rebeldia armada, de movimentos artísticos, literários e 'folclóricos' - toda essa complexa dinâmica, ostensiva ou encoberta, extemporânea ou cotidiana, constitui movimento negro (SANTOS, 1994, p. 157).

A histórica discriminação dos negros tem como fundamento a ideia de "raça", segundo a qual existem diferenças naturais entre os seres humanos. A esse respeito Platão deixou suas impressões no quinto livro da República e, séculos depois, essa ideia de diferenças naturais entre os homens ressurge na Europa com a publicação, em 1859, de "A origem das espécies", de Charles Darwin, na qual desenvolveu a teoria da seleção natural. Nos séculos que se seguem foram o tempo de invenção, (des)invenção e reinvenção do mito da raça. Hoje, através de estudos genéticos, sabemos que as diferenças entre humanos não passam de características físicas superficiais. “A cor da pele, a mais icônica das características "raciais", é uma mera adaptação evolutiva a diferentes níveis de radiação ultravioleta, expressa em menos de dez dos cerca de 25 mil genes do genoma humano" (MAGNOLI, 2009, p. 21).

O autor afirma, ainda, que "Raça é precisamente, a invenção de um gueto. O nome desse gueto é ancestralidade"(MAGNOLI, 2009, p.15). O que define a vida do indivíduo em termos raciais são os laços, reais ou fictícios, que o conecta com o passado. Mas a modernidade inicia-se com uma perspectiva oposta, que caminha em direção aos direitos de cidadania. Os cidadãos são postos em igualdade perante a lei e isso lhes permite "inventar" seu próprio futuro à revelia das origens familiares ou relações de sangue. A política de raças é uma negação da modernidade.

A negação multiculturalista da modernidade é um fenômeno moderno. "A ciência das raças" tem início no final do século XVIII, junto com a Revolução Francesa e a consolidação do conceito de cidadania, e vai se desenvolvendo de forma acentuada até a Segunda Guerra Mundial. As políticas de preferências raciais disseminaram-se no pós-guerra, principalmente depois da 
proclamação da Declaração Universal dos Direitos Humanos e do desprezo mundial ao racismo nazista. Para o multiculturalismo o princípio da igualdade pode ser uma bela declaração, mas a realidade verdadeira é constituída pelas diferenças essenciais entre as coletividades humanas.

O "racismo cientifico", segundo Magnoli(2009), definiu as raças como famílias humanas separadas pelas suas essências biológicas. Quando a ciência desmoralizou a crença nas "diferenças naturais", o multiculturalismo colocou as raças no campo da cultura. Assim, as raças são entidades sociais e culturais.

A produção das raças não exige distinções de cor da pele. Basta- como sabem os nigerianos, os quenianos e os ruandeses 'a elaboração de uma narrativa histórica organizada a partir de cânones étnicos e, crucialmente, a inscrição dos grupos raciais nas tábuas da lei. A distribuição dos privilégios segundo critérios de etnia ou raça grava nas consciências o senso de pertença racial. A raça é uma profecia autorealizável” (MAGNOLI, 2009, p.16).

No final do século XX, os cientistas que estudaram o genoma humano anunciaram a morte da raça. "O mito da raça, entretanto, no lugar de se dissolver como uma crença anacrônica, algo parecido com a antiga crenças em bruxas, permanece ou renasce na esfera pública, desafiando a utopia da igualdade"(MAGNOLI, 2009, p.16). Assim, os grupos humanos historicamente discriminados, como os negros, necessitam, pois, de ações políticas cada vez mais contundentes para livrarem-se de vez do "fantasma" da raça e de todos os malefícios dele decorrentes.

No movimento negro são gestadas as ações de combate ao racismo. Essas ações se traduzem, historicamente, num movimento de construção ou valorização de uma identidade, que mesmo após a abolição continuou sendo negada. É também um espaço onde pessoas negras, excluídas do processo social, econômico e educacional, encaminham suas lutas por políticas públicas de ações afirmativas, tentando reverter a situação de marginalização a que estão submetidas desde a abolição.

No Brasil os espaços políticos do movimento negro restringiam-se, a principio, basicamente aos estados de São Paulo e Rio de Janeiro, com quase inexistência desses movimentos em outros estados. A partir dos anos 1930, eles tomam dimensões mais amplas até que, em 1937, com a decretação do Estado Novo por Getúlio Vargas, todos os partidos políticos- inclusive a Frente Negra Brasileira, movimento negro surgido em São Paulo, em 1931 - foram declarados ilegais e dissolvidos. Desde então, e praticamente até a redemocratização, em 1945, os movimentos sociais 
negros tiveram de recuar para suas formas tradicionais de resistência cultural. A partir da década de 1950, esses movimentos sociais iniciam um lento ciclo de rearticulação cujo marco é a fundação, em São Paulo, em dezembro de 1954, da Associação Cultural do Negro (ACN).

Enquanto o governo Vargas (1930-1945) usava a repressão contra dissidentes politícos que dificultavam a unificação nacional, os intelectuais brasileiros, baseados nas ideias de Gilberto Freyre, "começam a explorar e alimentar o mito do Brasil como um paraiso social, que mais tarde, se tornaria conhecido como democracia racial” (DAVIS, 2000, p. 36). No final da década de 1930 "a forte ideologia do branqueamento desempenhou um papel importante na marginalização persistente dos pretos e mulatos - embora os brasileiros continuassem a celebrar a democracia racial" (DAVIS, 2000, p. 37).

Com a chegada dos anos 1960 veio a ditadura militar e, com ela, a desmobilização de todas as manifestações de caráter social e político. Ao mesmo tempo em que os militares transformaram o mito da "dempcracia racial" em discurso de sua propaganda oficial, qualificaram os militantes que insistiam em levantar o tema da discriminação como "impatrióticos", "racistas" e "imitadores baratos" dos ativistas estadunidensa que lutavam pelos direitos civis (HANCHARD, 2000).

Apesar de todos os embates entre o Estado e o movimento negro, este nunca fora completamente aniquilado, ressurgindo sempre que o sistema vigente deixava espacar alguma brecha para isso. O contexto do ressurgimento do movimento negro pode ser compreendido a partir das análise de Ribeiro(2000) ao afirmar que:

No final dos anos 70, o movimento negro, que esteve desmobilizado desde a implantação do governo militar, o governo Médici, ressurge no Brasil e passa a se constituir uma nova fase do processo histórico das mobilizações negras. Apesar de ser o período mais repressivo do regime militar, nele começa a retomada dos negros contra o preconceito e a discriminação racial, principalmente influenciados por acontecimentos em nível nacional e internacional como a abertura política, os movimentos de libertação dos países africanos, a radicalização da luta pelos direitos civis no Estados Unidos e a libertação de Angola ( RIBEIRO, 2000, p. 90).

No âmago do movimento negro em geral encontra-se o movimento social quilombola. Tais movimentos se diferenciam pelo fato do segundo colocar na sua agenda de reivindicações, além dos direitos gerais extensivos a todos os cidadãos, os direitos específicos das comunidades 
quilombolas como a posse das terras dos quilombos, respaldada no Artigo 68 do ADCT (Ato das Disposições Constitucionais Transitórias) da Constituição Federal de 1988, sendo esta a questão motriz do movimento quilombola e também uma das causas dos conflitos agrários estabelecidos no campo, nos últimos anos.

A partir do início da década de 1990, segundo Arruti,

Uma jovem militância quilombola emerge em todo o país, herdeira da luta dos pais e avós - que muitas vezes a travaram dentro dos sindicatos, sob o rótulo genérico de posseiros ou trabalhadores rurais - mas realimentada por uma nova política atual, formada a partir da influência do discurso negro urbano (ARRUTI, 2003,p. 2).

Surge, assim, o movimento nacional das comunidades negras rurais quilombolas, hoje um dos mais ativos agentes do movimento negro rural no Brasil. O atual processo de reconhecimento e titulação das comunidades quilombolas no Brasil tem gerado grande número de conflitos agrários, o que exige dessas populações uma articulação cada vez maior. Evidentemente que tais conflitos sempre existiram no país, em maior ou menor intensidade, mas, nos últimos, tempos têm adquirido outras dimensões, principalmente a partir dos direitos conquistados por grupos negros e índios desde a Constituição de 1988.

Esses direitos não se consolidam na promulgação da lei, nem resolvem os problemas territoriais entre grupos étnicos distintos. Muitas das terras hoje demarcadas como terras dos quilombos são as mesmas que, durante muito anos estiveram(ou estão) sob posse de fazendeiros que as passaram para seus descendentes como direito de herança. Muitos desses herdeiros possuem escrituras das terras - legais ou não- e são eles que lutam contra os quilombolas e pela manutenção da posse da terra, ou lutam na Justiça para receberem da União uma indenização que julgam ter direito, para então poder entregá-las às comunidades de quilombos.

O movimento quilombola contemporâneo insere-se no contexto dos "novos movimentos sociais" que (re)surgiram a partir da década de 1970, tendo suas raízes fincadas no processo de escravização dos negros que vigorou no Brasil desde a colonização até praticamente o final do Império. Os militantes desse movimento buscaram(e ainda buscam) na escravidão vivida por seus ancestrais, no passado, instrumentos históricos e culturais que lhes confiram uma identidade quilombola. 
A Constituição Federal de 1988 instituiu, através do artigo 68 da ADCT, as comunidades quilombolas como sujeitos de direito, ao conceder-lhes o direito à propriedade das terras ocupadas pela população dessas comunidades. No entanto, mesmo com a instituição do direito à terra, essas comunidades precisam intensificar suas ações políticas para que o mesmo seja efetivado e, nessa luta pela efetivação desse e de outros direitos, as comunidades quilombolas atuais vão constituindo um dos mais ativos movimentos sociais as atualidade: o movimento quilombola.

\section{Considerações finais}

A instituição da escravidão negra engendrada no âmbito do sistema capitalismo moderno europeu constitui-se atualmente num dos aspectos mais negativos da história da humanidade. Toda essa negatividade decorre das condições ultrajantes às quais os negros africanos foram submetidos durante o processo de escravização. Escravizados, homens e mulheres perderam a sua "humanidade" ao terem seus corpos, suas vidas, suas histórias e culturas reduzidos a uma única condição: a de mercadoria.

A escravização de seres humanos entre os séculos XVI e XIX, tornou-se uma atividade econômica altamente lucrativa, mas não era uma tarefa fácil para os envolvidos nesse "negócio". Todo período de existência da escravidão foi atravessado pelas mais variadas formas de luta esboçadas pelos escravizados contra o sistema opressor que lhes roubava a dignidade humana e, em muitos casos, a própria vida. Recusa deixar a África, revoltas, fugas, assassinatos, suicídios, formação de quilombos, estiveram entre as principais formas de reação oferecidas esboçadas pelas vítimas da escravidão.

A história da resistência à escravidão no Brasil atravessou os três séculos de existência desse sistema. Esse fato contraria qualquer noção de docilidade e aceitação passiva por parte dos escravizados às condições a que foram submetidos. Ao resistirem, de diversas maneiras, além de negarem a naturalidade daquele infausta instituição, os escravos foram desmontando lentamente a estrutura do sistema que lhes vitimavam.

Além de desumano o sistema escravista era também contraditório. As próprias concepções teóricas/ideológicas que davam sustentação ao capitalismo moderno - do qual a escravidão fazia parte-, a exemplo o liberalismo, cujo principal fundamento era a liberdade, chocavam-se com a 
existência da instituição escrava, uma vez que esta tolhia a liberdade de seres humanos e transformava-os em mercadoria.

A contradição entre Liberalismo Escravismo, fez-se presente em importantes momentos da história do Brasil, dos quais dois podem ser destacados: 1- No período colonial alguns os movimentos separatistas de cunho liberal, defendiam a liberdade política da colônia, mas não propunha a extinção da escravidão; 2- No Brasil Imperial, a Constituição de 1824, de inspiração liberal, manteve a instituição escrava intocada, o que levou Roberto Schwarz, nomear essa situação de comédia ideológica.

A resistência escrava ganhou reforço na segunda metade do século XIX com o surgimento do movimento abolicionista compostos pelas camadas liberais da sociedade brasileira. A pressão contra a escravidão adquiriu tamanha força em algumas regiões do Brasil que os próprios senhores de escravos perderam totalmente o controle sobre a situação. Não restou alternativa ao Estado Imperial a não ser antecipar-se ao golpe final sobre o sistema escravista e decretar o fim da instituição escrava, em 1888. No ano seguinte, 1889, o próprio sistema monárquico, através do golpe militar que instituiu a República.

A Escravidão e a Monarquia no Brasil foram abolidos no final do século XIX. O advento da República era a esperança de novos tempos para as camadas pobres da sociedade brasileira. No entanto, "os novos tempos" fizeram-se acompanhar das velhas práticas políticas excludentes; ao mesmo tempo em que a estrutura agrária continuou intocada, excluído todo um contingente de homens e mulheres do acesso à terra, onde poderiam garantir sua sobrevivência. $\mathrm{O}$ Estado republicano não possibilitou a inserção dos negros, ex-escravos, na sociedade de classe brasileira. A própria Constituição republicana de 1891, criou mecanismos de negação dos direitos de cidadania aos ex-escravos.

Destarte, os negros precisaram reinventar suas lutas. Agora não mais contra o sistema de escravidão, mas pela garantia de direitos e cidadania, contra as formas de exclusão social, os estereótipos e preconceitos raciais. Organizaram-se diversos os movimentos sociais, que no passado, assim como hoje, constituem formas de resistência dos afro-brasileiros. A Constituição brasileira de 1988 conferiu às comunidades negras contemporâneas o direito à titulação das terras que ocupam. Esse ato institui essas comunidades como sujeitos coletivos de direito e fortaleceu o movimento negro atual. 


\section{Referências bibliográficas}

ALMEIDA, Alfredo Wagner Berno de. O Direito Étnico a Terra. In: Boletim Orçamento \& Política Socioambiental. Ano IV, $\mathrm{n}^{\circ} 13$, junho de 2005.

Alfredo Wagner Berno de( Coord).Terra nosso bem maior. In: Nova cartografia dos povos e comunidades tradicionais do Brasil: Quilombolas de Conceição das Crioulas, Salgueiro/PE. Brasília-DF, PNCS-PCTB, 2007.

ANDRADE Manuel Correia de. Abolição e Reforma Agrária. São Paulo: Ática, 1987.

Pernambuco - cinco séculos de colonização. João Pessoa/PB, 2004.

ARRUTI, José Maurício. Relatório técnico científico sobre os remanescentes da comunidade de quilombo de Cangume município de Itaóca - SP. ITESP, São Paulo: 2003. Disponível no site: http://www.itesp.sp.gov.br/br/info/acoes/rtc/RTC Cangume.pdf. Acessado em 01/01/11.

BRASIL . Constituição (1988). Constituição da República Federativa do Brasil. Brasília: Senado Federal, 2006.

COHN, Gabriel. Florestan Fernandes - A integração do negro na sociedade de classes. In: MOTA, Lourenço Dantas (org) - Introdução ao Brasil 2 - um banquete no trópico. São Paulo: Editora SENAC, 2002.

CARVAlHO, José Murilo. Cidadania no Brasil - um longo caminho. Rio de Janeiro: Civilização Brasileira, 2001.

COSTA, Emília Viotti da. Da monarquia à república: momentos decisivos. São Paulo: Fundação Editora UNESP, 2007. , Emília Viotti. Abolição. São Paulo: UNESP, 2008.

DAVIS, Darien J. Afro-brasileiros Hoje. São Paulo: Summus, 2000.

FERRAZ, Socorro. Liberais \& Liberais: Guerras Civis em Pernambuco, no século XIX. Recife: Editora Universitária, 1996.

FUNES, Eurípedes Antônio. "Nasci nas matas, nunca tive senhor": história e memória dos Mocambos do Baixo Amazonas. Tese de Doutorado. São Paulo, USP, 1995 (mimeo).

GOHN, Maria da Glória. Movimentos e lutas sociais na história do Brasil. São Paulo: Loyola, 1995.

HANCHARD, Michael George. 'Orfeu e o poder: o movimento negro no Rio de Janeiro e São Paulo (1945-1988). Rio de Janeiro, 2000.

MAGNOLI, Demétrio. Uma gota de sangue - história do pensamento racial. São Paulo: Contexto, 2009.

MATTOS, Regiane Augusto de. História e cultura afro-brasileira. São Paulo: Contexto, 2007. 
MATTOS, Hebe Maria. Escravidão e Cidadania no Brasil Monárquico. Rio de Janeiro: Jorge Zahar Editor, 2004.

MUNANGA, Kabengele. Origem e histórico do Quilombo na África. Revista USP. n.28, p- 5663. São Paulo. 1996. Disponível em: 16/04/ 17.

PINSK, Jaime. A escravidão no Brasil- as razões da escravidão, sexualidade e vida cotidiana, as formas de resistência. São Paulo : Contexto, 2000.

PLATÃO, A República. Trad. Enrico Corvisieri. São Paulo: Nova Cultural, 2004.

REIS, João José e Gomes, Flávio dos Santos. Liberdade Por um Fio - história dos quilombos no Brasil. São Paulo: Companhia das Letras, 1996.

RIBEIRO, Cristiane Maria. Anti-racismo e educação: o projeto político pedagógico das lideranças negras de Uberlândia. Dissertação de mestrado. Uberlândia/MG, URB: 2000. (mimeo).

SANTOS, J.R. Movimento negro e crise brasileiras. Ministério da Cultura/Fundação Cultural Palmares: Brasília, 1994.

SCHWARZ, Roberto(org). "Ao Vencedor as Batatas". São Paulo: Duas Cidades, 1992. 